\title{
Preventing dance injuries: current perspectives
}

\section{Jeffrey A Russell}

Division of Athletic Training, School of Applied Health Sciences and Wellness, Ohio University, Athens, $\mathrm{OH}$, USA

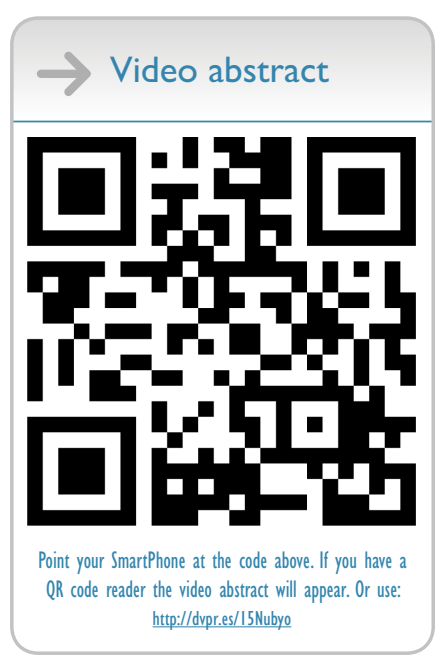

Correspondence: Jeffrey A Russell Ohio University, School of Applied Health Sciences and Wellness, Grover Center E335, Athens, OH 4570I, USA $\mathrm{Tel}+\mathrm{I} 7405934648$

Fax + I 7405930289

Email jeff.russell@ohio.edu
This article was published in the following Dove Press journal:

Open Access Journal of Sports Medicine

27 September 2013

Number of times this article has been viewed

\begin{abstract}
Dancers are clearly athletes in the degree to which sophisticated physical capacities are required to perform at a high level. The standard complement of athletic attributes - muscular strength and endurance, anaerobic and aerobic energy utilization, speed, agility, coordination, motor control, and psychological readiness - all are essential to dance performance. In dance, as in any athletic activity, injuries are prevalent. This paper presents the research background of dance injuries, characteristics that distinguish dance and dancers from traditional sports and athletes, and research-based perspectives into how dance injuries can be reduced or prevented, including the factors of physical training, nutrition and rest, flooring, dancing en pointe, and specialized health care access for dancers. The review concludes by offering five essential components for those involved with caring for dancers that, when properly applied, will assist them in decreasing the likelihood of dance-related injury and ensuring that dancers receive optimum attention from the health care profession: (1) screening; (2) physical training; (3) nutrition and rest; (4) specialized dance health care; and (5) becoming acquainted with the nature of dance and dancers.
\end{abstract}

Keywords: dance, injuries, injury prevention, fitness, wellness, health

\section{Introduction}

Among activities in the realm of sports, dance is typically not included. Nonetheless, dancers are clearly athletes in the degree to which they require sophisticated physical capacities to perform at a high level. The standard complement of athletic attributes - muscular strength and endurance, anaerobic and aerobic energy utilization, speed, agility, coordination, motor control, and psychological readiness - are all essential for dance performance. In dance, as in any athletic activity, injuries are prevalent. However, as is also true in traditional sports, the prevention of injury is preferable to the management of injury; ie, maximizing a participant's ability to engage in his or her chosen pursuit without injury is the ultimate goal.

In light of these assertions, the purposes of this review are: (1) to highlight the current state of knowledge about injuries in dance with a view toward injury prevention; (2) to equip clinicians, researchers, and others who work with dancers with information that will assist them in providing optimum care; and (3) to offer motivation for additional health, wellness, and health care personnel to embrace the practice of caring for dancers. The main approach taken herein is to elucidate many of the idiosyncrasies and challenges inherent in dance medicine that are typically not seen in sports medicine. This will serve as a means to provide the reader with an appreciation for how to approach dance injury prevention and management. 


\section{The nature of dance, injury, and dance injury research}

The prevention of dance injuries hinges in part on an adequate research foundation about the incidence of these injuries, yet there are several aspects of such research that present obstacles. Dance as an art form is a collective of a variety of genres, some of which are becoming increasingly difficult to categorize because they are influenced by two or more styles. Thus, the term "dancer" is often troublesome to delineate secondary to participants commonly possessing skills in multiple genres or to the differences in skills required among genres. For example, "dancer" may be applied to anyone who participates in genres such as ballet, modern, contemporary, jazz, tap, hip-hop, ballroom, musical theater, and a variety of ethnic forms like flamenco, Irish, African, and countless other versions subscribed to virtually every nation. Nonetheless, it is tenuous at best to imply that research on "ballet dancers" generalizes across all "dancers." Furthermore, particularly in dance practice outside of professional, pre-professional, and ethnic groups (eg, individuals in university dance training), it is common for dancers to regularly engage in several genres.

A simple, cursory search of the Medline database easily indicates that, to date, ballet has received the greatest scientific research focus; just the article title search term "ballet" generates more than 350 articles since 1952. This is followed in level of attention in the literature, perhaps surprisingly, by break dance ${ }^{1-21}$ (usually referred to as breaking by its participants, who are called "b-boys" and "b-girls"), and modern/contemporary dance. ${ }^{22-40}$ Other dance genres that have received research consideration, though comparatively not as much, include hip-hop, ${ }^{41}$ flamenco,${ }^{42-44}$ ballroom, ${ }^{45-51}$ Highland, ${ }^{52,53}$ and Irish. ${ }^{54-60}$ Investigation of some of these is becoming more frequent.

One of the difficulties with the current dance injury literature is its history of multiple definitions for what constitutes an injury and the lack of a standard injury reporting system, problems addressed in detail by the Standard Measures Consensus Initiative of the International Association for Dance Medicine and Science. ${ }^{61}$ This group of researchers offers three primary purposes of its work:

1. Establish uniform methodology for tests and measures used to assess dancer capacities and intrinsic and extrinsic risk factors for injury;

2. Establish common protocols for reporting injuries;

3. Assist the dance medicine community in applying these recommendations [via] all applicable technologies. ${ }^{61}$
Noting that identification of an occurrence as an "injury" only if it results in time lost from an individual's activity is the typical model for epidemiological reporting, the consensus statement also specifies several caveats that may affect injury reporting data, such as a participant's motivation, pain tolerance, and peer influence, as well as a team's coaching philosophy (or, in the case of dance, teaching philosophy) ${ }^{61}$ Access to proper medical care and a facility's or practitioner's relative attentiveness to recordkeeping also may affect both the quality and quantity of injury data collection.

While ideal data may not be available, dance is undoubtedly associated with numerous injuries. . $3,24,39,41,60,62-84$ In research reporting the percentage of dancers injured out of a studied sample, the range was $42 \%-97 \%$ across a variety of genres and skill proficiencies. ${ }^{63,64,66,68,69,71,73,85-88}$ The lower extremities have been shown repeatedly to be the most commonly injured region of the body in dancers. ${ }^{63,64,67,68,71,75,76,79,80,82,83,85,88-90}$ Nonetheless, the physical requirements of specific genres may dictate injury location, such as a higher proportion of injuries occurring in the upper extremity ${ }^{29,75}$ and back ${ }^{40,75}$ in modern or contemporary dance compared to ballet as a result of the former's dependence on floor-based and partner maneuvers that require substantial weightbearing involvement by the upper extremities. For dance injuries occurring in children and adolescents aged 19 years and younger, increasing age has been associated with increasing likelihood of injury to the lower extremity versus the upper extremity. ${ }^{82}$

Roberts et al ${ }^{82}$ reviewed 17 years of National Electronic Injury Surveillance System (United States) data for individuals aged 3 to 19 . They identified a total of 113,084 dancerelated injuries in this age group during the span of the study, with the number of cases and the annual age-adjusted rate of injury both increasing substantially during the span of years studied. Investigations that include injuries to dancers across their careers report that $84 \%$ to $95 \%$ of dancers are affected. ${ }^{68,87,91}$

In a 1-year prospective study of professional ballet dancers, Allen et a ${ }^{83}$ tabulated 355 injuries in 52 dancers, or a mean of nearly seven injuries per dancer in that single year. The researchers' injury definition was any condition that prevented a dancer from participating fully in normally scheduled dance activities for at least 24 hours from the time the injury occurred. The incidence was 4.4 injuries per 1,000 hours of dance exposure, and overuse injuries were the most commonly reported type in this sample $(64 \%$ of injuries in females and $68 \%$ in males). Females had a mean time-loss from dance due to injury of 4 days, while males' mean time-loss was 9 days. This study is exemplary in that 
the high injury rate spurred the authors to implement an injury reduction program in their ballet company.

All of the literature taken together indicates, then, that the reduction of injury incidence in dancers is a worthwhile, if elusive, target. The task is multi-faceted, and certainly replete with opportunities for additional high-quality research engagement. For further insight into systematically approaching dance injury research, the reader is referred to Liederbach et al's technical report. ${ }^{61}$

\section{Challenges in caring for dancers versus traditional athletes}

While highly tuned physical capacities are as important for dancers as they are for athletes, there are important differences between these two types of participants and between their activities. These factors impact the application of both preventive and treatment measures within the dance community.

Sports, in most cultures, are widely played, as well as followed by an enormous fan base. Interest extends from the highest professional ranks to the remotest of children's playgrounds. Dance, on the other hand, does not enjoy such cultural pervasiveness (nor do any of the performing or visual arts, for that matter) even though the art form is taught in many schools and universities, and worldwide there are immensely talented and popular dance companies. Overall, most dancers, dance teachers, choreographers, and dance funding patrons describe feeling a lack of appreciation and respect by society at large for their extraordinarily physical and aesthetic craft. Despite this, they are never dissuaded from pursuing its creation, rehearsal, and performance, as the very nature of dance as athletic artistry engenders a high degree of dedication in its participants. This motivation informs virtually every aspect of their participation and presents some unique challenges to clinicians.

In contrast to most athletes who engage in daily practice sessions that are of comparatively short duration, dancers may routinely participate in technique classes during most of any given day, followed by rehearsals through the late afternoons and evenings. Weekends may be similarly filled. They feel an obligation to participate in and perfect their art, and conversations with and observations of dancers corroborate for the health care professional the intense psyche these athletic artists possess. Ballet dancers, in particular, exhibit a consuming passion for dance that makes a decision to stop dancing for injury or other reasons exceedingly difficult, a frame of mind Wainwright et $\mathrm{al}^{92}$ liken to an addiction.
One difficulty in assessing and monitoring dance injuries is dancers' extraordinary processing of pain. They exhibit both a higher pain threshold (the amount of pain required for them to acknowledge it) and a higher pain tolerance (their ability to disregard pain while participating in physical activity) than non-dancers. ${ }^{93}$ This also may play a role in dancers' minimalist reports of pain that do not seem to correlate with the presence of imaging findings. ${ }^{94,95}$ In addition, Anderson and Hanrahan ${ }^{96}$ noted that ballet dancers tended to distinguish poorly between pain that is customary in dance performance and pain associated with injury. Pain is typically seen by dancers as an accompanying facet of dance practice, and dancers are prone to "dance through" pain, even when doing so may be detrimental. ${ }^{97}$ Moreover, their pain coping skills are not as developed as those seen in many types of sports participants. ${ }^{98}$ These points should be helpful to anyone caring for injured dancers.

\section{Psychosocial and technical factors related to dance injuries}

Injuries are considered by dancers to be a natural, even necessary, part of participating in dance. ${ }^{92}$ Toledo et al ${ }^{99}$ suggest several contributors to dance injuries (Table 1). These should serve only as a general baseline, however, as research into dance injuries becomes more sophisticated with concomitant access to an ever wider cross-section of dancers, including increasingly popular genres like hip-hop ${ }^{41}$ and breaking, ${ }^{2,4}$ as well as young dancers..$^{82,89,100}$ Note that most of the factors in Table 1 are modifiable or treatable, thus making prevention more realistic. This and other references ${ }^{101,102}$ suggest that improved health care for dancers may result from a psychosocial approach wherein health care providers become conversant with the nature of dance practice and performance in order to effectively assist dancers in preventing and recovering from injuries.

Adam et al, ${ }^{103}$ Patterson et al, ${ }^{104}$ and Hamilton et al ${ }^{105}$ all found that negative stressors in ballet dancers' lives predicted an increased injury rate. However, they also found that this effect could be mediated by the presence of positive social support in the dancers' lives. Two examples of stressors suggested by Noh et $\mathrm{al}^{106}$ that are associated with a heightened risk of injury in ballet dancers are worry and negative confidence in one's dance abilities. In another study, these researchers determined that ballet dancers who are taught general psychological coping skills experienced fewer injuries and less time injured. ${ }^{107}$ Among professional ballet dancers, females tend to be more disciplined than males. Women portray a tougher personality than their male colleagues in 
Table I Contributors to dance injury

\begin{tabular}{|c|c|c|}
\hline $\begin{array}{l}\text { General } \\
\text { cause }\end{array}$ & Specific cause & $\begin{array}{l}\text { Alterable with } \\
\text { conservative } \\
\text { management? }\end{array}$ \\
\hline \multirow[t]{4}{*}{$\begin{array}{l}\text { Improper } \\
\text { training }\end{array}$} & $\begin{array}{l}\text { Lack of warm-up exercise } \\
\text { routine }\end{array}$ & Yes \\
\hline & Repetitive jumping & Yes \\
\hline & Poor alignment of body weight & Yes \\
\hline & Disregarded overuse/fatigue & Yes \\
\hline \multirow[t]{5}{*}{$\begin{array}{l}\text { Faulty } \\
\text { technique }\end{array}$} & $\begin{array}{l}\text { "Sickling" (forefoot/hindfoot } \\
\text { varus in demi-pointe or en pointe) }\end{array}$ & Yes \\
\hline & $\begin{array}{l}\text { "Winging" (forefoot/hindfoot } \\
\text { valgus in demi-pointe or en pointe) }\end{array}$ & Yes \\
\hline & $\begin{array}{l}\text { "Rolling in" } \\
\text { (foot hyperpronation) }\end{array}$ & Yes \\
\hline & $\begin{array}{l}\text { Poor turnout (inadequate } \\
\text { hip external rotation) }\end{array}$ & Somewhat \\
\hline & Anterior pelvic tilt & Yes \\
\hline Environmental & Hard floors & Depends on facility \\
\hline \multirow[t]{2}{*}{ hazard } & III-fitting shoes & Yes \\
\hline & Barefoot dancing & $\begin{array}{l}\text { Depends on genre* } \\
\text { and instructor }\end{array}$ \\
\hline Structural & Hallux rigidus & Somewhat \\
\hline deformity & Hallux valgus & Somewhat \\
\hline \multirow[t]{2}{*}{ of the foot } & Pes cavus (high arch) & No, but treatable \\
\hline & Pes planus (flat foot) & No, but treatable \\
\hline Biomechanical & Poor core strength & Yes \\
\hline \multirow[t]{5}{*}{ imbalance } & $\begin{array}{l}\text { Weak eccentric strength } \\
\text { of leg muscles }\end{array}$ & Yes \\
\hline & $\begin{array}{l}\text { Pelvic muscle imbalance } \\
\text { or inflexibility }\end{array}$ & Yes \\
\hline & Tight Achilles' tendon & Somewhat \\
\hline & Hypermobility syndrome & No, but \\
\hline & (Beighton score $\geq 4$ ) & manageable \\
\hline
\end{tabular}

Notes: *Barefoot dancing is integral (and, thus, unmodifiable) to many dance forms; eg, modern/contemporary and several ethnic genres.

Adapted from Arch Phys Med Rehabil, 85(3 Suppl I), Sports and performing arts medicine. 6. Issues relating to dancers, S75-S78, Copyright 2004, with permission from Elsevier. ${ }^{99}$ The table has been reconfigured for clarity. Items in italics are additions to Toledo et al's list, as are the commentaries in the rightmost column.

the face of the demands of a professional dance career, along with generally having fewer negative psychological traits. ${ }^{105}$ In addition, data from this study present a difficult enigma in suggesting that the same personality characteristics that promote success in ballet also place a dancer at increased risk of injury.

Technical intricacies required for success in particular dance genres may predispose dancers to injury. That is, aesthetic demands that are part of any given style of dance are typically not alterable. For example, "turnout" - externally rotating the hips and lower extremities to place the feet as close as possible to an ideal angle of $180^{\circ}$ with each other - is a fundamental component of ballet. But, many dancers force this position beyond their normal limits, a practice that may result in conditions such as foot pronation, ${ }^{35}$ low back pain associated with anterior pelvic tilt, ${ }^{108,109}$ and pain and injury in joints of the lower extremity. ${ }^{35,109}$ Younger dancers or dancers who are less well trained are especially susceptible because they strive for a technical performance level for which their bodies may not be suited or properly instructed. ${ }^{110}$

In keeping the technical demands of dance from increasing the chance of injury, ensuring that dancers receive appropriately qualified instruction is paramount. However, poor teaching may be a difficult factor for health care providers to assuage unless they have both a dance background and unusually good access to the teachers of dancers under their care or in their community. Organizations such as the International Association for Dance Medicine and Science (IADMS, www.iadms.org) are important assets; IADMS holds a yearly educational day for dance teachers in conjunction with its annual conference, as well as produces resources designed specifically to foster healthy dance instruction.

\section{Injury prevention factors in dance Physical training}

As previously described in light of a substantial body of research, dancers sustain many injuries. Research about preventive strategies to mitigate the incidence of dance injuries is less voluminous. Malkogeorgos et al ${ }^{111}$ offer five main areas of attention for preventing dance injuries: warm-up, training (including muscular strength, power, and endurance; plyometrics; agility; balance; joint stability; and dance-specific technique), equipment (including footwear and surfaces); regulatory aspects (rules and regulations governing dance); and self-care prevention and treatment methods. Of these, training is the most expansive area, and one that perhaps holds the most promise for success in reducing the incidence of dance injuries.

Participation in dance is not sufficiently intense across long durations to substantially improve aerobic capacity, ${ }^{31,112,113}$ and low cardiorespiratory endurance has been associated with dance injuries. ${ }^{114}$ In adolescent female dance students, O'Neill et al ${ }^{115}$ found that moderate-to-vigorous physical activity was lowest in the highest level dance classes, though students with more dance training generally tended to be more active in their classes than students with less training. Further, they noted that ballet classes offered less time for physical activity than did jazz and tap classes. Overall, the dance students they studied were moderately to vigorously active for only 10 minutes per hour of dance classes. In a study of modern dancers, Wyon et $\mathrm{al}^{31}$ found, not surprisingly, that participating in dance performances resulted in significantly higher heart rates and greater mean oxygen 
uptakes than either dance classes or rehearsals. Activity heart rates in their cohort of dancers were only rarely at a level consistent with that needed for aerobic improvement.

An investigation of ballet dancers suggested that inadequate physical training was a primary contributor to dance injuries. ${ }^{78}$ However, a 6-year follow-up of the same dancers revealed that, while they still were frequently injured, their increased age and dance workload did not result in more pain or injuries; rather, improved physical training facilities were identified as a helpful adjunct to their dance activity. ${ }^{116}$ Furthermore, professional ballet dancers who participated in a fitness program apart from their dance technical training showed an increase in maximum oxygen uptake, as well as decreased psychological stress, in comparison to a control group of dancers who did not pursue a fitness program. ${ }^{117}$

A study suggesting that decreased injury incidence in professional ballet dancers results from implementing physical training was performed by Allen et al. ${ }^{84}$ Over 3 years of prospective injury recording, male dancers' injury incidence dropped from 4.76 per 1,000 hours of dance exposure to 2.22 per 1,000 hours. Injury incidence for females declined from 4.14 to 1.81 per 1,000 hours in the same 3-year period. Based on their first year's data, these researchers incorporated individualized conditioning programs based on each dancer's injury history and physical screening data and subsequently showed the value of such programs in reducing ballet injuries. As one possibility, physical regimens already popular with dancers, such as Pilates, ${ }^{30}$ should be encouraged and greater intensity and training volume across a general fitness program are advisable.

Whereas poor core stability has been identified as a risk factor for upper ${ }^{118}$ and lower ${ }^{119}$ extremity injury, and inadequate neuromuscular control in the trunk has been specifically associated with increased athletic knee injuries in females, ${ }^{120}$ dancers' attention to these components of fitness is warranted. In elite professional ballet dancers, smaller cross-sectional area of the multifidus muscles have been correlated with lower back pain. ${ }^{121}$ The trunk muscles appear to fire in anticipation of lower extremity muscle contraction; ${ }^{122}$ this suggests the importance of optimal core function as the aesthetics of dance are intimately dependent on precise control of both the trunk and extremities. Therefore, attention to core stability and strength should be considered foundational to the remainder of a dancer's training with the caveat that further research on core function in dancers is needed in light of Rickman et al's ${ }^{123}$ findings that the research literature on this topic is relatively scant.
Low levels of muscular strength and power also have been suggested as predictive of dance injuries. ${ }^{22,124,125}$ Specifically, thigh torque in a cohort of male and female ballet and contemporary dancers was correlated with severity of injury as measured in days lost from dancing. ${ }^{124}$ Angioi et al $^{22}$ similarly found leg power measured by vertical jump height to be positively correlated with days lost from dancing. In support of the need for physical training by dancers, a 6-week program of circuit and vibration training of contemporary dancers led to improvement in lower body muscular power, upper body muscular endurance, aerobic fitness, and aesthetic competence. $^{34}$

Ambegaonkar et $\mathrm{al}^{33}$ studied upper body muscular endurance in university modern dancers, finding no difference between dancers and non-dancers in spite of modern dance requiring more consistent work with the upper body than ballet, especially in females. They surmised that their dancers' lack of engagement in upper body physical training outside of dance classes, rehearsals, and performances was the primary contributor, thereby suggesting that participation in modern dance, in and of itself, does not lead to upper body muscular training effects.

In a sample of female professional ballet dancers compared to a control group, Koutedakis and Sharp ${ }^{126}$ reported significant improvements in quadriceps and hamstring torque output, as well as improvement in thigh muscle fatigability during dance, as a result of 12 weeks of strength training for these muscles. The improvements were particularly noteworthy in dancers who were weaker at the beginning of the study. As the control group dancers did not exhibit strength increases, the authors suggested that dance technical training alone is incapable of eliciting strength gains. Undesirable increases in muscle bulk are a concern for many female dancers because of the importance of anatomical aesthetic contours in dance. However, importantly for females, the increases in thigh strength seen in this study occurred without a concomitant alteration of thigh circumference, a finding the researchers offer as an indicator that the aesthetic characteristics of the lower extremities can be preserved when female ballet dancers participate in weight training. ${ }^{126}$

In view of the research evidence, it seems wise to recommend that dancers take part in general fitness training, not only as a helpful supplement to their technical training and performance, but as a means to reduce their chance of injury.

\section{Nutrition and rest}

Suboptimal nutrition has been associated with injury in dancers. ${ }^{127,128}$ Disordered eating and eating disorders - a discussion 
of which is beyond the scope of this review - are well known to affect many dancers. ${ }^{129-132}$ In addition, physiques generally associated with female ballet dancers, ie, high ectomorphy, low mesomorphy, and low percent body fat, have been linked to increased injury. ${ }^{133}$ Ballet dancers are particularly prone to control their physiques, especially via restricted dietary practices, because of the aesthetic requirements of their genre, as well as the related issue of the pressure to manage every detail of their existence as a means to maintain their place in a dance company. Many dancers may not follow sound research-based nutritional practices; thus, health care practitioners should utilize well-documented advice in encouraging dancers toward a healthy energy and fluid intake. Excellent resources for this purpose include the joint position statement on nutrition for sports performance developed by the American Dietetic Association, Dietitians of Canada, and the American College of Sports Medicine. ${ }^{134}$

Fatigue has been proposed as a risk factor for injuries in physical activity. ${ }^{135-139}$ In addition, fatigue manifest as "burnout" was shown to have a negative effect on several physical performance variables in professional female classical ballet dancers. ${ }^{140,141}$ Typical schedules of dancers that include dance classes and rehearsals throughout much of any given day may not be conducive to rest unless dancers purposely ensure they find time for adequate breaks and leisure. Also, dance seasons may not incorporate as much off-season recovery time as most sports seasons do. University dance students especially might be at risk of not receiving necessary rest because of the combination of their dance practice, the requirements of their non-dance academic work, and, often, their need to maintain employment to cover their personal expenses.

While research about fatigue and rest in dancers appears scarce, Twitchett et al ${ }^{142}$ mapped female professional ballet dancers' activity across a typical workday. Ninety percent of the dancers took less than 60 consecutive minutes of rest, and one-third took less than 20 minutes rest during the day. In a 5-year prospective study of both ballet and modern dancers, more injuries tended to occur in the evening, toward the end of the season, and during performances; these all suggest fatigue as a contributing factor. ${ }^{75}$ Thus, dancers must be encouraged to schedule appropriate "down time" in support of both their physical and emotional health.

\section{Flooring}

Most dancers prefer to dance on a "sprung" floor rather than on an unyielding surface such as concrete. Sprung floors are typically manufactured from wood and are set on a subfloor by means of a framework of dense foam blocks or other resilient material that effectively suspends the wood floor above the hard subfloor. In many genres of dance that utilize studios and stages, the wood is covered with a 1-2 mm thick vinyl sheet called "marley" in the dance vernacular. The suspended, or sprung, nature of the floor allows it to disperse some of the forces associated with dance, particularly in jumping and landing. ${ }^{143,144}$ Unfortunately, in many instances dancer preference must give way to the necessity of dancing on whatever surface is installed in a given school, studio, or theater. Hopper et $\mathrm{al}^{145}$ found great variability in force reduction capability amongst different professional ballet venues, concluding that none of the floors met suggested standards for force reduction and that the floor with the greatest intrasurface variability in force reduction was the floor on which the most injuries occurred.

The shock absorptive quality of the surface may not be the only floor-related hazard associated with dance injuries, however. Wanke et al ${ }^{146}$ attributed $12.7 \%$ of all accidents (291 of 2,281 reported injuries spanning 17 years) in professional and student dancers to a fault with flooring. The most common complaint from the injured dancers was a slippery floor, with the second most common being too much friction in the interface between the foot/shoe and the floor. The majority of the injuries to the professionals occurred on a stage surface, and about half of the professionals' injuries occurred during performances. In response to these data, optimal maintenance practices are essential to ensuring a surface properly prepared for the type of dance to be performed on the floor and the footwear to be worn (or the lack of footwear for some genres). However, this responsibility rests with the dance facility and, therefore, hazardous conditions may be outside the influence of a health care provider unless he or she is employed by the responsible dance company or university.

\section{Footwear}

Most genres of dance employ specific types of shoes, although modern/contemporary dancers and certain ethnic style dancers do not wear shoes. Unshod dancers are especially challenging when foot orthotics are indicated for treatment or prevention of injury. Dance shoes in genres that require them (eg, ballet, jazz, tap, flamenco, Irish) are minimally force dispersive by nature of their construction. Ballet slippers, jazz shoes, and Irish dance shoes are little more than a layer or two of leather or microfiber material. Flamenco shoes have high heels suggested to be a cause of injuries to the feet and lower back. ${ }^{42,43}$ Despite the possibility that cushioned shoes help dissipate energy when landing on a floor ${ }^{77,147}$ and provide shock absorption to reduce the 
chance of lower limb pathology, ${ }^{148}$ dancers are unlikely to incorporate these into their rehearsals because they need to precisely replicate their performance conditions and because the specific "feel" of the floor by their feet is essential to their success in dancing.

Pointe shoes in ballet are supportive of the foot, having been shown to provide stiffness with compromise of the midfoot ligaments. ${ }^{149}$ They are a necessity for en pointe technique, but have been associated with foot pain and injuries. ${ }^{150,151}$ Their ability to dissipate force through the sole appears to be better than ballet slippers. ${ }^{152}$ Some evidence suggests that a soft, partial pointe (ie, demi-pointe) shoe is helpful in reducing leg, ankle, and foot injuries in adolescent dancers when these shoes are worn as a prelude to initiating pointe training. ${ }^{153}$

Certainly, research on footwear in dance is insufficient at present. ${ }^{154}$ In short, health care providers must work within the constraints of the footwear - or lack of footwear - customary within the dance genres practiced by their dancer-patients.

\section{Dancing en pointe}

Dancing en pointe is a specific type of ballet that can give rise to numerous injuries in young dancers if proper care is not exercised in deciding when a dancer is ready to begin pointe training. ${ }^{155,156}$ It requires an extreme amount of plantar flexion $^{157-159}$ that includes motion among the bones of the feet ${ }^{160}$ in order to stand on the toe tips in pointe shoes (Figure 1). The physical test - among several evaluated - found to be most associated with appropriate readiness for pointe work is the "Airplane test," stability. The dancer stands on one leg while bending over at the waist and extending the other leg backward such that it and the trunk are parallel to the floor. In this position, then, the dancer is facing downward at the floor. The upper extremities are extended outward from the shoulders, also parallel to the floor. The dancer then lowers herself by flexing the knee of the support leg, simultaneously keeping the trunk and nonsupport leg parallel to the floor and bringing the fingertips of both hands downward, while maintaining extended elbows, to touch the floor in front of the face. The dancer then extends the knee and upper extremities to return to the starting position. Four out of five consecutive trials performed with good balance and without valgus or varus motion of the support knee are required to pass the test. ${ }^{161}$

Other factors related to success in moving to ballet en pointe include foot strength, ankle range of motion, stability and control during rising to the toes and lowering, and seriousness of ballet training as evidenced by the number

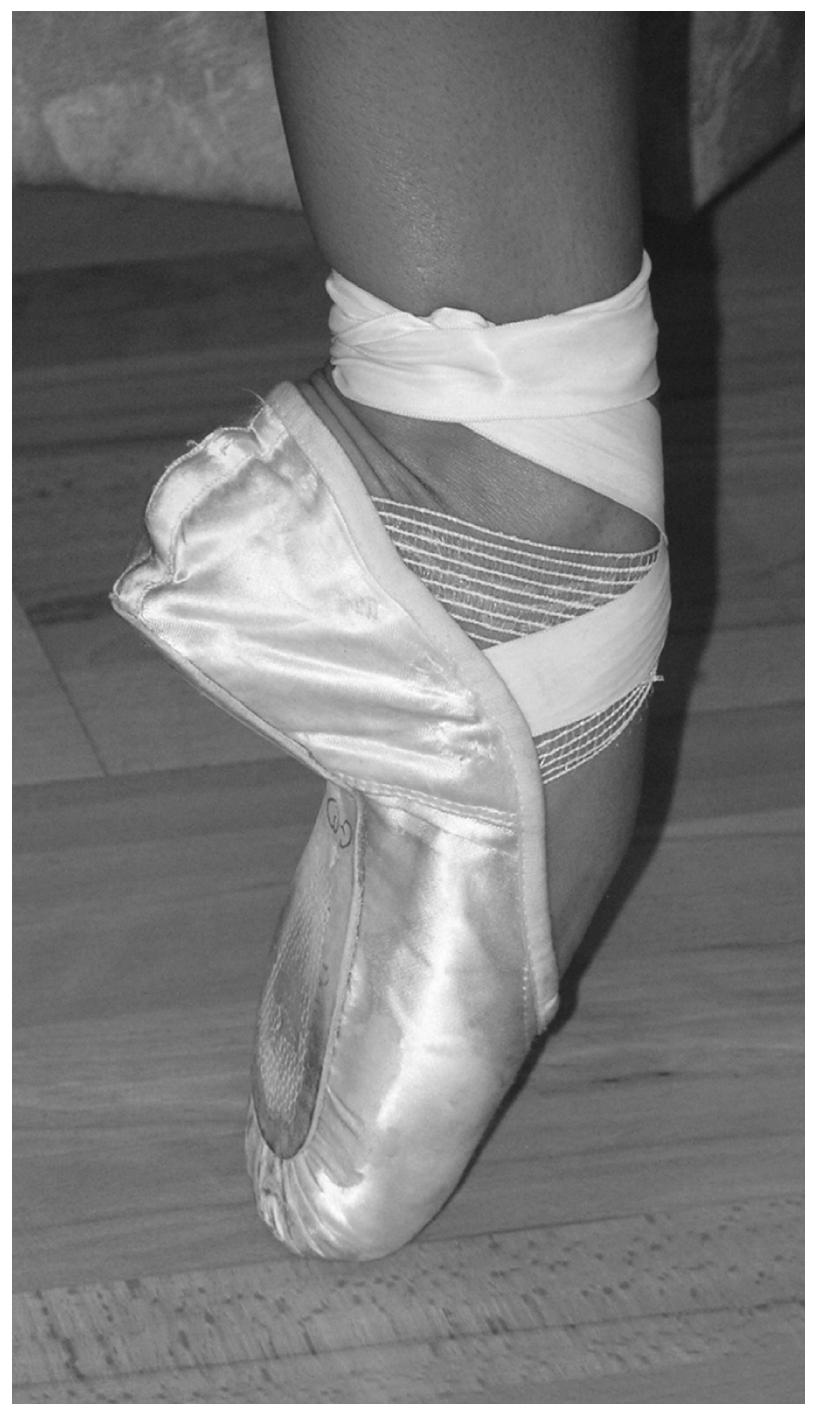

Figure I A ballet dancer standing en pointe. Note the extreme talocrural plantar flexion and the architecture of the midfoot, the combination of which is required for the dancer to attain this position.

of days and hours per week the student attends ballet classes. ${ }^{155,156}$ Implementing solely an age-based criterion for advancement to pointe is not appropriate ${ }^{88,156}$ Health care providers who have occasion to consult with young dancers and their parents about dancing en pointe should become conversant with the demands of this activity.

\section{Specialized health care access for dancers}

Most dancers do not enjoy access to specialized health care that is equivalent to their counterparts in traditional sports. . $^{30,162-164}$ Moreover, when they do approach the health care profession, the response they receive is often unconstructive or, even, discouraging. ${ }^{40,165-167}$ Russell and Wang ${ }^{167}$ found that $80 \%$ of university dancers surveyed reported that they felt their health care providers did not understand dancers and $43 \%$ 
indicated that their health care providers gave unhelpful advice. Empirically, most dancers will report at least one - and often several - instances of being told by a practitioner to "stop dancing" as a method to manage their injuries. While this advice is sound under certain injury circumstances that require complete rest (eg, a tibial stress fracture), dancers loathe receiving it as a carelessly offered, supposed panacea. From the perspective of artists, health care workers could better serve them by purposefully learning about performing arts medicine ${ }^{168}$ and by attending dance performances as a method for understanding the physical demands of dance. ${ }^{165}$ If reduction or discontinuance of dancing is warranted for an injury, one method of improving the relationship between providers and dancers, and better serving the physical nature of dance, is for those in health care to prescribe rehabilitative regimens that either moderate dancers' dancing or define suitable activity alternatives during recuperative periods (rather than suggest they "stop dancing").

Appropriate, specialized health care for dancers is necessary not only for proper care of injuries, but for prevention of new injuries or worsening of current injuries. For example, anterior leg pain that a dancer considers as "shin splints" - and a corollary of participating in dance - may have disastrous sequelae. As one dramatic illustration of this, Martinez and Murphy ${ }^{169}$ described their experience with a male professional ballet dancer exhibiting a radiologically confirmed tibial stress fracture in the anterior cortex that did not respond to conventional treatment. To address this, intramedullary nailing was performed. However, the dancer did not seek consistent follow-up care, and 4 months postsurgery he landed from a jump, re-fractured the tibia, and bent the nail, thus necessitating revision surgery.

Notably, Bronner et $\mathrm{al}^{24}$ reported a substantial decrease in time-loss injury incidence and a concomitant decrease in medical expenditures following implementation of a health care program in a professional modern dance company. They compared injury records for 2 years without health care intervention against the records for 3 years with provision of comprehensive care. Their definition of injury was "any musculoskeletal complaint resulting in financial outlay". Injury rates, measured by the quantity of new workers' compensation claims amongst the company's dancers, dropped markedly, declining from about $80 \%$ across the first 3 years of the study to $24 \%$ in the fourth year and $17 \%$ in the fifth year. The number of injuries per 1,000 hours of dance exposure also fell.

In a follow-up study, Ojofeitimi and Bronner ${ }^{39}$ slightly refined their injury definition: "a physical insult that required financial outlay (WC [workers' compensation] or self insurance) or caused a dancer to cease dancing beyond the day of injury (time-loss injury)". They studied a further 3 years of data from their experience with the professional modern dance company and found overall that the company exhibited a 34\% decrease in injury incidence, $66 \%$ fewer workers' compensation claims, and a 56\% decline in days lost from dance. These two studies are highlighted because they imply that attentive health care for dancers, both preventive and restorative, is associated with amelioration of injury rates.

\section{Conclusion}

Dance is a rigorous physical activity accompanied by a large quantity of injuries in its participants. In spite of some similarities dance shares with sports, a number of differences and challenges present themselves to those charged with caring for dancers. Several elements related to how dancers approach their art form are worthy of consideration in determining how best to reduce their injuries. In summary, and in light of the literature review presented above, the following current perspectives are offered to professionals in dance, health, research, and health care to support reducing and preventing dance-related injuries.

1. Screening of dancers' physical and psychological attributes, prior injuries, and current and planned dance activity can identify areas that should be addressed to minimize the likelihood of injury.

2. Physical training of dancers, apart from their technical training in dance, should be encouraged, with special attention to the core and to the musculature specific to the demands of their genre(s).

3. Proper nutrition and rest (reduction of fatigue) are essential factors in maintaining a dancer's body that is as resistant to injury as possible.

4. The provision of specialized health care services to dancers is important to risk assessment, injury management, and injury reduction.

5. Health care practitioners not conversant with dance or the psyche of performing artists will become more appreciative of dance's physically rigorous nature, be better equipped to care for dance injuries, and gain favor with dancers by observing different varieties of dance and interacting with dancers about their art form.

\section{Disclosure}

The author reports no conflict of interest in this work. 


\section{References}

1. Cho CH, Song KS, Min BW, Bae KC, Lee KJ, Kim SH. Scaphoid nonunion in break-dancers: a report of 3 cases. Orthopedics. 2009; 32(7):526.

2. Cho CH, Song KS, Min BW, Lee SM, Chang HW, Eum DS. Musculoskeletal injuries in break-dancers. Injury. 2009;40(11): 1207-1211.

3. Kauther MD, Wedemeyer C, Kauther KM, Weidle PA, Wegner A, von Knoch M. Breakdancer's "Headspin Hole" - first description of a common overuse syndrome. Sportverletz Sportschaden. 2009;23(1):52-53. German.

4. Kauther MD, Wedemeyer C, Wegner A, Kauther KM, von Knoch M. Breakdance injuries and overuse syndromes in amateurs and professionals. Am J Sports Med. 2009;37(4):797-802.

5. Winkler AR, Barnes JC, Ogden JA. Break dance hip: chronic avulsion of the anterior superior iliac spine. Pediatr Radiol. 1987;17(6):501-502.

6. Balfour-Lynn IM. Break dancer's lung. Arch Dis Child. 2002; 86(3):224.

7. Broome HE, Heppenstall RB. 'Break dancers' bursitis'. JAMA. 1985; 253(6): 777 .

8. Byun HS, Cantos EL, Patel PP. Severe cervical injury due to break dancing. A case report. Orthopedics. 1986;9(4):550-551.

9. Dieden JD. Break dancer's fracture of the fifth metatarsal. West J Med. 1985;142(1):101.

10. Dorey RS, Mayne V. Break-dancing injuries. Med J Aust. 1986;144(11): 610-611.

11. Gerber SD, Griffin PP, Simmons BP. Break dancer's wrist. J Pediatr Orthop. 1986;6(1):98-99.

12. Goscienski PJ, Luevanos L. Injury caused by 'break dancing'. JAMA. 1984;252(24):3367.

13. Joondeph BC, Spigelman AV, Pulido JS. Ocular trauma from break dancing. Arch Ophthalmol. 1986;104(2):176-177.

14. Khoury JJ, Loberant N, Jerushalmi J. Shoulder pain in a young break-dancer evaluated with bone scintigraphy. Clin $\mathrm{Nucl} \mathrm{Med}$. 2009;34(12):916-917.

15. Lee $\mathrm{KC}$, Clough $\mathrm{C}$. Intracerebral hemorrhage after break dancing. N Engl J Med. 1990;323(9):615-616.

16. Leung AK. Hazards of break dancing. N Y State J Med. 1984; 84(12):592.

17. McBride DQ, Lehman LP, Mangiardi JR. Break-dancing neck. N Engl J Med. 1985;312(3):186.

18. Monselise A, Chan LJ, Shapiro J. Break dancing: a new risk factor for scarring hair loss. J Cutan Med Surg. 2011;15(3):177-179.

19. Norman RA, Grodin MA. Injuries from break dancing. Am Fam Physician. 1984;30(4):109-112.

20. Schneider F, Milesi I, Haesler E, Wicky S, Schnyder P, Denys A. Break-dance: an unusual cause of hammer syndrome. Cardiovasc Intervent Radiol. 2002;25(4):330-331.

21. Sharma V, Knapp JK, Wasserman GS, Walsh I, Hoover CJ. Injuries associated with break dancing. Pediatr Emerg Care. 1986;2(1):21-22.

22. Angioi M, Metsios GS, Koutedakis Y, Twitchett E, Wyon MA. Physical fitness and severity of injuries in contemporary dance. Med Probl Perform Art. 2009;24:26-29.

23. Baker J, Scott D, Watkins K, Keegan-Turcotte S, Wyon M. Self-reported and reported injury patterns in contemporary dance students. Med Probl Perform Art. 2010;25(1):10-15.

24. Bronner S, Ojofeitimi S, Rose D. Injuries in a modern dance company: effect of comprehensive management on injury incidence and time loss. Am J Sports Med. 2003;31(3):365-373.

25. da Silva AH, Bonorino KC. BMI and flexibility in ballerinas of contemporary dance and classical ballet. Fitness Perf J. 2008;7(1):48-51.

26. Fuhrmann TL, Brayer A, Andrus N, McIntosh S. Injury prevention for modern dancers: a pilot study of an educational intervention. J Community Health. 2010;35(5):527-533.

27. Koutedakis Y, Hukam H, Metsios G, et al. The effects of three months of aerobic and strength training on selected performance- and fitnessrelated parameters in modern dance students. $J$ Strength Cond Res. 2007;21(3):808-812.
28. Shick J, Stoner LJ, Jette N. Relationship between modern-dance experience and balancing performance. Res $Q$ Exerc Sport. 1983;54(1): 79-82.

29. Sides SN, Ambegaonkar JP, Caswell SV. High incidence of shoulder injuries in collegiate modern dance students. Athl Ther Today. 2009; 14(4):43-46.

30. Weiss DS, Shah S, Burchette RJ. A profile of the demographics and training characteristics of professional modern dancers. J Dance Med Sci. 2008;12(2):41-46.

31. Wyon MA, Abt G, Redding E, Head A, Sharp NC. Oxygen uptake during modern dance class, rehearsal, and performance. J Strength Cond Res. 2004;18(3):646-649.

32. Wyon MA, Redding E. Physiological monitoring of cardiorespiratory adaptations during rehearsal and performance of contemporary dance. J Strength Cond Res. 2005;19(3):611-614.

33. Ambegaonkar JP, Caswell SV, Winchester JB, Caswell AA, Andre MJ. Upper-body muscular endurance in female university-level modern dancers: a pilot study. J Dance Med Sci. 2012;16(1):3-7.

34. Angioi M, Metsios G, Twitchett EA, Koutedakis Y, Wyon M. Effects of supplemental training on fitness and aesthetic competence parameters in contemporary dance: a randomised controlled trial. Med Probl Perform Art. 2012;27(1):3-8.

35. Cimelli SN, Curran SA. Influence of turnout on foot posture and its relationship to overuse musculoskeletal injury in professional contemporary dancers: a preliminary investigation. J Am Podiatr Med Assoc. 2012;102(1):25-33.

36. Friesen KJ, Rozenek R, Clippinger K, Gunter K, Russo AC, Sklar SE. Bone mineral density and body composition of collegiate modern dancers. J Dance Med Sci. 2011;15(1):31-36.

37. Karim A, Millet V, Massie K, Olson S, Morganthaler A. Inter-rater reliability of a musculoskeletal screen as administered to female professional contemporary dancers. Work. 2011;40(3):281-288.

38. Langdon SW, Petracca G. Tiny dancer: Body image and dancer identity in female modern dancers. Body Image. 2010;7(4):360-363.

39. Ojofeitimi S, Bronner S. Injuries in a modern dance company effect of comprehensive management on injury incidence and cost. J Dance Med Sci. 2011;15(3):116-122.

40. Shah S, Weiss DS, Burchette RJ. Injuries in professional modern dancers: incidence, risk factors, and management. J Dance Med Sci. 2012;16(1):17-25.

41. Ojofeitimi S, Bronner S, Woo H. Injury incidence in hip hop dance. Scand J Med Sci Sports. 2012;22(3):347-355.

42. Bejjani FJ, Halpern N, Pio A, Dominguez R, Voloshin A, Frankel VH. Musculoskeletal demands on flamenco dancers: a clinical and biomechanical study. Foot Ankle. 1988;8(5):254-263.

43. Pedersen ME, Wilmerding MV. Injury profiles of student and professional flamenco dancers. J Dance Med Sci. 1998;2(3): 108-114.

44. Shybut TB, Rose DJ, Strongwater AM. Second metatarsal physeal arrest in an adolescent flamenco dancer: a case report. Foot Ankle Int. 2008;29(8):859-862.

45. Berndt C, Strahler J, Kirschbaum C, Rohleder N. Lower stress system activity and higher peripheral inflammation in competitive ballroom dancers. Biol Psychol. 2012;91(3):357-364.

46. Blanksby BA, Reidy PW. Heart rate and estimated energy expenditure during ballroom dancing. Br J Sports Med. 1988;22(2):57-60.

47. Kattenstroth JC, Kalisch T, Kolankowska I, Dinse HR. Balance, sensorimotor, and cognitive performance in long-year expert senior ballroom dancers. J Aging Res. 2011;2011:176709.

48. Tsung PA, Mulford GJ. Ballroom dancing and cervical radiculopathy: a case report. Arch Phys Med Rehabil. 1998;79(10):1306-1308.

49. Kuisis SM, Camacho T, Kruger PE, Camacho AL. Self-reported incidence of injuries among ballroom dancers. Afr J Phys Health Educ Rec Dance. 2012;18(Suppl 1):107-119.

50. McCabe TR, Hopkins JT, Vehrs P, Draper DO. Contributions of muscle fatigue to a neuromuscular neck injury in female ballroom dancers. Med Probl Perform Art. 2013;28(2):84-90. 
51. McCabe TR, Wyon M, Ambegaonkar JP, Riding E. A Bibliographic Review of Medicine and Science Research in DanceSport. Med Probl Perform Art. 2013;28(2):70-79.

52. Baillie Y, Wyon M, Head A. Highland dance: heart-rate and blood lactate differences between competition and class. Int J Sports Physiol Perform. 2007;2(4):371-376.

53. Henderson J, MacIntyre D. A descriptive survey of injury patterns in Canadian Premier Highland dancers. Physiother Can. 2006;58(1): 61-73.

54. Cromie S, Greenwood JG, McCullagh JF. Does Irish-dance training influence lower-limb asymmetry? Laterality. 2007;12(6):500-506.

55. McCauley A, Lamb KL. An assessment of the prevalence and correlates of injuries in Irish dancers [Abstract]. J Sports Sci. 2004;22(3):251.

56. Walls RJ, Brennan SA, Hodnett P, O’Byrne JM, Eustace SJ, Stephens MM. Overuse ankle injuries in professional Irish dancers. Foot Ankle Surg. 2010;16(1):45-49.

57. Trégouët $P$, Merland $F$. The effects of different shoes on plantar forces in Irish dance. J Dance Med Sci. 2013;17(1):41-46.

58. Shippen JM, May B. Calculation of muscle loading and joint contact forces during the rock step in Irish dance. J Dance Med Sci. 2010;14(1): $11-18$.

59. O'Halloran E, Vioreanu M, Padinjarathala B. "Between the jigs and the reels": bilateral metatarsal phalangeal stress fractures in a young Irish dancer. Clin J Sport Med. 2011;21(5):454-455.

60. Noon M, Hoch AZ, McNamara L, Schimke J. Injury patterns in female Irish dancers. PM R. 2010;2(11):1030-1034.

61. Liederbach M, Hagins M, Gamboa JM, Welsh TM. Assessing and reporting dancer capacities, risk factors, and injuries: recommendations from the IADMS Standard Measures Consensus Initiative. J Dance Med Sci. 2012;16(4):139-153.

62. Bronner S, Ojofeitimi S, Spriggs J. Occupational musculoskeletal disorders in dancers. Phys Ther Rev. 2003;8:57-68.

63. Byhring S, Bø K. Musculoskeletal injuries in the Norwegian National Ballet: a prospective cohort study. Scand J Med Sci Sports. 2002;12(6):365-370.

64. Nilsson C, Leanderson J, Wykman A, Strender LE. The injury panorama in a Swedish professional ballet company. Knee Surg Sports Traumatol Arthrosc. 2001;9(4):242-246.

65. Askling C, Lund H, Saartok T, Thorstensson A. Self-reported hamstring injuries in student-dancers. Scand J Med Sci Sports. 2002;12(4): 230-235.

66. Kerr G, Krasnow D, Mainswaring L. The nature of dance injuries. Med Probl Perform Art. 1992;7:25-29.

67. Washington EL. Musculoskeletal injuries in theatrical dancers: site frequency, and severity. Am J Sports Med. 1978;6(2):75-98.

68. Bowling A. Injuries to dancers: prevalence, treatment, and perceptions of causes. BMJ. 1989;298(6675):731-734.

69. Laws H. Fit to Dance 2. London: Dance UK; 2005.

70. Sohl P, Bowling A. Injuries to dancers. Prevalence, treatment and prevention. Sports Med. 1990;9(5):317-322.

71. Rovere GD, Webb LX, Gristina AG, Vogel JM. Musculoskeletal injuries in theatrical dance students. Am J Sports Med. 1983;11(4):195-198.

72. Olsson I. A 2-year study of 77 dancers. Almost 90 per cent needed help because of injury. Lakartidningen. 1998;95(15):1689. Swedish.

73. Garrick JG, Requa RK. Ballet injuries. An analysis of epidemiology and financial outcome. Am J Sports Med. 1993;21(4):586-590.

74. Arendt YD, Kerschbaumer F. Injury and overuse pattern in professional ballet dancers. Z Orthop Ihre Grenzgeb. 2003;141(3):349-356. German.

75. Liederbach M, Dilgen FE, Rose DJ. Incidence of anterior cruciate ligament injuries among elite ballet and modern dancers: a 5-year prospective study. Am J Sports Med. 2008;36(9):1779-1788.

76. Ambegaonkar JP. Dance medicine: at the university level. Dance Res J. 2005;37(2):113-119.

77. Schon LC, Weinfeld SB. Lower extremity musculoskeletal problems in dancers. Curr Opin Rheumatol. 1996;8(2):130-142.
78. Ramel E, Moritz U. Self-reported musculoskeletal pain and discomfort in professional ballet dancers in Sweden. Scand J Rehabil Med. 1994;26(1):11-16.

79. Negus V, Hopper D, Briffa NK. Associations between turnout and lower extremity injuries in classical ballet dancers. $J$ Orthop Sports Phys Ther. 2005;35(5):307-318.

80. Hincapié CA, Morton EJ, Cassidy JD. Musculoskeletal injuries and pain in dancers: a systematic review. Arch Phys Med Rehabil. 2008;89(9):1819-1829.

81. Alderson J, Hopper L, Elliott B, Ackland T. Risk factors for lower back injury in male dancers performing ballet lifts. J Dance Med Sci. 2009;13(3):83-89.

82. Roberts KJ, Nelson NG, McKenzie L. Dance-related injuries in children and adolescents treated in US emergency departments in 1991-2007. J Phys Act Health. 2013;10(2):143-150.

83. Allen N, Nevill A, Brooks J, Koutedakis Y, Wyon M. Ballet injuries: injury incidence and severity over 1 year. J Orthop Sports Phys Ther. 2012;42(9):781-790.

84. Allen N, Nevill AM, Brooks JH, Koutedakis Y, Wyon MA. The Effect of a Comprehensive Injury Audit Program on Injury Incidence in Ballet: A 3-Year Prospective Study. Clin J Sport Med. 2013.

85. Gamboa JM, Roberts LA, Maring J, Fergus A. Injury patterns in elite preprofessional ballet dancers and the utility of screening programs to identify risk characteristics. J Orthop Sports Phys Ther. 2008;38(3): 126-136.

86. Solomon R, Solomon J, Micheli LJ, McGray E Jr. The 'cost' of injuries in a professional ballet company. Med Probl Perform Art. 1999;14: $164-169$.

87. Thomas H, Tarr J. Dancers' perceptions of pain and injury: positive and negative effects. J Dance Med Sci. 2009;13(2):51-59.

88. Steinberg N, Siev-Ner I, Peleg S, et al. Extrinsic and intrinsic risk factors associated with injuries in young dancers aged 8-16 years. J Sports Sci. 2012;30(5):485-495.

89. Steinberg N, Siev-Ner I, Peleg S, et al. Injuries in female dancers aged 8 to 16 years. J Athl Train. 2013;48(1):118-123.

90. Campoy FA, Coelho LR, Bastos FN, et al. Investigation of risk factors and characteristics of dance injuries. Clin J Sport Med. 2011;21(6): 493-498.

91. Luke AC, Kinney SA, D'Hemecourt PA, Baum J, Owen M, Micheli LJ. Determinants of injuries in young dancers. Med Probl Perform Art. 2002;17(3):105-112.

92. Wainwright SP, Williams C, Turner BS. Fractured identities: injury and the balletic body. Health (London). 2005;9(1):49-66.

93. Tajet-Foxell B, Rose FD. Pain and pain tolerance in professional ballet dancers. Br J Sports Med. 1995;29(1):31-34.

94. Russell JA, Shave RM, Yoshioka H, Kruse DW, Koutedakis Y, Wyon MA. Magnetic resonance imaging of the ankle in female ballet dancers en pointe. Acta Radiol. 2010;51(6):655-661.

95. Duthon VB, Charbonnier C, Kolo FC, et al. Correlation of clinical and magnetic resonance imaging findings in hips of elite female ballet dancers. Arthroscopy. 2013;29(3):411-419.

96. Anderson R, Hanrahan SJ. Dancing in pain: pain appraisal and coping in dancers. J Dance Med Sci. 2008;12(1):9-16.

97. Mainwaring LM, Hutchison M, Bisschop SM, Comper P, Richards DW. Emotional response to sport concussion compared to ACL injury. Brain Inj. 2010;24(4):589-597.

98. Encarnacion MLG, Meyers MC, Ryan ND, Pease DG. Pain coping styles of ballet performers. J Sport Behav. 2000;23(1):20-32.

99. Toledo SD, Akuthota V, Drake DF, Nadler SF, Chou LH. Sports and performing arts medicine. 6. Issues relating to dancers. Arch Phys Med Rehabil. 2004;85(3 Suppl 1):S75-S78.

100. Hiller CE, Refshauge KM, Herbert RD, Kilbreath SL. Intrinsic predictors of lateral ankle sprain in adolescent dancers: a prospective cohort study. Clin J Sport Med. 2008;18(1):44-48.

101. Russell JA. Musculoskeletal Dance Medicine and Science. In: Magee DJ, Manske RC, Zachazewski JE, Quillen WS, editors. Athletic and Sport Issues in Musculoskeletal Rehabilitation. St Louis: Elsevier Saunders; 2011:651-680. 
102. Russell JA. Breaking pointe: foot and ankle injuries in dance. Low Extrem Rev. 2012;4(1):18-22.

103. Adam MU, Brassington GS, Matheson GO. Psychological factors associated with performance-limiting injuries in professional ballet dancers. J Dance Med Sci. 2004;8(2):43-46.

104. Patterson EL, Smith RE, Everett JJ, Ptacek JT. Psychosocial factors as predictors of ballet injuries: interactive effects of life stress and social support. J Sport Behav. 1998;21(1):101-112.

105. Hamilton LH, Hamilton WG, Meltzer JD, Marshall P, Molnar M. Personality, stress, and injuries in professional ballet dancers. Am J Sports Med. 1989;17(2):263-267.

106. Noh YE, Morris T, Andersen MB. Psychosocial factors and ballet injuries. IJSEP. 2005;3(1):79-90.

107. Noh YE, Morris T, Andersen MB. Psychological intervention programs for reduction of injury in ballet dancers. Res Sports Med. 2007;15(1):13-32.

108. Drężewska M, Śliwiński Z. Lumbosacral pain in ballet school students. Pilot study. Ortop Traumatol Rehabil. 2013;15(2):149-158.

109. Clippinger K. Dance Anatomy and Kinesiology. Champaign: Human Kinetics; 2007.

110. Hamilton WG. Foot and ankle injuries in dancers. Clin Sports Med. 1988;7(1):143-173

111. Malkogeorgos A, Mavrovouniotis F, Zaggelidis G, Ciucurel C. Common dance related musculoskeletal injuries. J Phys Educ Sport. 2011;11(3):259-266.

112. Twitchett EA, Koutedakis Y, Wyon MA. Physiological fitness and professional classical ballet performance: a brief review. J Strength Cond Res. 2009;23(9):2732-2740.

113. Koutedakis Y, Jamurtas A. The dancer as a performing athlete: physiological considerations. Sports Med. 2004;34(10):651-661.

114. Twitchett E, Brodrick A, Nevill AM, Koutedakis Y, Angioi M, Wyon M. Does physical fitness affect injury occurrence and time loss due to injury in elite vocational ballet students? J Dance Med Sci. 2010;14(1):26-31.

115. O’Neill JR, Pate RR, Beets MW. Physical activity levels of adolescent girls during dance classes. J Phys Act Health. 2012;9(3): 382-388.

116. Ramel EM, Moritz U, Jarnlo G-B. Recurrent musculoskeletal pain in professional ballet dancers in Sweden: a six-year follow-up. J Dance Med Sci. 1999;3(3):93-100.

117. Ramel E, Thorsson O, Wollmer P. Fitness training and its effect on musculoskeletal pain in professional ballet dancers. Scand J Med Sci Sports. 1997;7(5):293-298.

118. Peate WF, Bates G, Lunda K, Francis S, Bellamy K. Core strength: a new model for injury prediction and prevention. J Occup Med Toxicol. 2007;2:3

119. Willson JD, Dougherty CP, Ireland ML, Davis IM. Core stability and its relationship to lower extremity function and injury. $\mathrm{J} \mathrm{Am} \mathrm{Acad}$ Orthop Surg. 2005;13(5):316-325.

120. Zazulak BT, Hewett TE, Reeves NP, Goldberg B, Cholewicki J. Deficits in neuromuscular control of the trunk predict knee injury risk: a prospective biomechanical-epidemiologic study. Am J Sports Med. 2007;35(7):1123-1130.

121. Gildea JE, Hides JA, Hodges PW. Size and Symmetry of Trunk Muscles in Ballet Dancers With and Without Low Back Pain. J Orthop Sports Phys Ther. 2013

122. Hodges PW, Richardson CA. Contraction of the abdominal muscles associated with movement of the lower limb. Phys Ther. 1997;77(2): 132-142; discussion 142-144.

123. Rickman AM, Ambegaonkar JP, Cortes N. Core stability: implications for dance injuries. Med Probl Perform Art. 2012;27(3):159-164.

124. Koutedakis Y, Khaloula M, Pacy PJ, Murphy M, Dunbar GMJ. Thigh peak torques and lower-body injuries in dancers. J Dance Med Sci. 1997;1(1):12-15.

125. Koutedakis Y, Stavropoulos-Kalinoglou A, Metsios G. The significance of muscular strength in dance. J Dance Med Sci. 2005;9(1): 29-34.
126. Koutedakis Y, Sharp NC. Thigh-muscles strength training, dance exercise, dynamometry, and anthropometry in professional ballerinas. $J$ Strength Cond Res. 2004;18(4):714-718.

127. Frusztajer NT, Dhuper S, Warren MP, Brooks-Gunn J, Fox RP. Nutrition and the incidence of stress fractures in ballet dancers. Am J Clin Nutr. 1990;51(5):779-783.

128. Benson JE, Geiger CJ, Eiserman PA, Wardlaw GM. Relationship between nutrient intake, body mass index, menstrual function, and ballet injury. J Am Diet Assoc. 1989;89(1):58-63.

129. Ringham R, Klump K, Kaye W, et al. Eating disorder symptomatology among ballet dancers. Int J Eat Disord. 2006;39(6):503-508.

130. Thomas JJ, Keel PK, Heatherton TF. Disordered eating attitudes and behaviors in ballet students: examination of environmental and individual risk factors. Int J Eat Disord. 2005;38(3): 263-268.

131. Thomas JJ, Keel PK, Heatherton TF. Disordered eating and injuries among adolescent ballet dancers. Eat Weight Disord. 2011;16(3): e216-e222.

132. Nascimento AL, Luna JV, Fontenelle LF. Body dysmorphic disorder and eating disorders in elite professional female ballet dancers. Ann Clin Psychiatry. 2012;24(3):191-194.

133. Twitchett E, Angioi M, Metsios GS, Koutedakis Y, Wyon MA. Body composition and ballet injuries: a preliminary study. Med Probl Perform Art. 2008;23:93-98.

134. American College of Sports Medicine; American Dietetic Association; Dietitians of Canada. Joint Position Statement: nutrition and athletic performance. American College of Sports Medicine, American Dietetic Association, and Dietitians of Canada. Med Sci Sports Exerc. 2000;32(12):2130-2145

135. Chappell JD, Herman DC, Knight BS, Kirkendall DT, Garrett WE, $\mathrm{Yu}$ B. Effect of fatigue on knee kinetics and kinematics in stop-jump tasks. Am J Sports Med. 2005;33(7):1022-1029.

136. Gefen A. Biomechanical analysis of fatigue-related foot injury mechanisms in athletes and recruits during intensive marching. Med Biol Eng Comput. 2002;40(3):302-310.

137. McLean SG, Fellin RE, Felin RE, et al. Impact of fatigue on genderbased high-risk landing strategies. Med Sci Sports Exerc. 2007;39(3): $502-514$.

138. McLean SG, Samorezov JE. Fatigue-induced ACL injury risk stems from a degradation in central control. Med Sci Sports Exerc. 2009;41(8):1661-1672.

139. Vetter RE, Symonds ML. Correlations between injury, training intensity, and physical and mental exhaustion among college athletes. J Strength Cond Res. 2010;24(3):587-596.

140. Koutedakis Y, Myszkewycz L, Soulas D, Papapostolou V, Sullivan I, Sharp NC. The effects of rest and subsequent training on selected physiological parameters in professional female classical dancers. Int J Sports Med. 1999;20(6):379-383.

141. Koutedakis Y. "Burnout" in dance: the physiological viewpoint J Dance Med Sci. 2000;4(4):122-127.

142. Twitchett E, Angioi M, Koutedakis Y, Wyon M. The demands of a working day among female professional ballet dancers. J Dance Med Sci. 2010;14(4):127-132.

143. Hackney J, Brummel S, Becker D, Selbo A, Koons S, Stewart M. Effect of sprung (suspended) floor on lower extremity stiffness during a force-returning ballet jump. Med Probl Perform Art. 2011;26(4): 195-199.

144. Hackney J, Brummel S, Jungblut K, Edge C. The effect of sprung (suspended) floors on leg stiffness during grand jeté landings in ballet. J Dance Med Sci. 2011;15(3):128-133.

145. Hopper LS, Allen N, Wyon M, Alderson JA, Elliott BC, Ackland TR. Dance floor mechanical properties and dancer injuries in a touring professional ballet company. J Sci Med Sport. 2013.

146. Wanke EM, Mill H, Wanke A, Davenport J, Koch F, Groneberg DA. Dance floors as injury risk: analysis and evaluation of acute injuries caused by dance floors in professional dance with regard to preventative aspects. Med Probl Perform Art. 2012;27(3):137-142. 
147. Yeow CH, Lee PV, Goh JC. Shod landing provides enhanced energy dissipation at the knee joint relative to barefoot landing from different heights. Knee. 2011;18(6):407-411.

148. Baitch SP. A biomechanical approach to aerobic dance injuries. In: Solomon R, Solomon J, Minton SC, editors. Preventing Dance Injuries: An Interdisciplinary Perspective. 2nd ed. Champaign: Human Kinetics; 2005.

149. Kadel N, Boenisch M, Teitz C, Trepman E. Stability of Lisfranc joints in ballet pointe position. Foot Ankle Int. 2005;26(5):394-400.

150. Nunes NM, Haddad JJ, Bartlett DJ, Obright KD. Musculoskeletal injuries among young, recreational, female dancers before and after dancing in pointe shoes. Pediatr Phys Ther. 2002;14(2):100-106.

151. Tuckman AS, Werner FW, Bayley JC. Analysis of the forefoot on pointe in the ballet dancer. Foot Ankle. 1991;12(3):144-148.

152. Walter HL, Docherty CL, Schrader J. Ground reaction forces in ballet dancers landing in flat shoes versus pointe shoes. J Dance Med Sci. 2011;15(2):61-64.

153. Pearson SJ, Whitaker AF. Footwear in classical ballet: a study of pressure distribution and related foot injury in the adolescent dancer. J Dance Med Sci. 2012;16(2):51-56.

154. Fong Yan A, Hiller C, Smith R, Vanwanseele B. Effect of footwear on dancers: a systematic review. J Dance Med Sci. 2011;15(2): 86-92.

155. Shah S. Determining a young dancer's readiness for dancing on pointe. Curr Sports Med Rep. 2009;8(6):295-299.

156. Weiss DS, Rist RA, Grossman G. When can I start pointe work? Guidelines for initiating pointe training. J Dance Med Sci. 2009;13(3): 90-92.

157. Hamilton WG, Hamilton LH, Marshall P, Molnar M. A profile of the musculoskeletal characteristics of elite professional ballet dancers. Am J Sports Med. 1992;20(3):267-273.

158. Russell JA, Kruse DW, Nevill AM, Koutedakis Y, Wyon MA. Measurement of the extreme ankle range of motion required by female ballet dancers. Foot Ankle Spec. 2010;3(6):324-330.
159. Russell JA, Shave RM, Kruse DW, Nevill AM, Koutedakis Y, Wyon MA. Is goniometry suitable for measuring ankle range of motion in female ballet dancers? An initial comparison with radiographic measurement. Foot Ankle Spec. 2011;4(3):151-156.

160. Russell JA, Shave RM, Kruse DW, Koutedakis Y, Wyon MA. Ankle and foot contributions to extreme plantar- and dorsiflexion in female ballet dancers. Foot Ankle Int. 2011;32(2):183-188.

161. Richardson M, Liederbach M, Sandow E. Functional criteria for assessing pointe-readiness. J Dance Med Sci. 2010;14(3):82-88.

162. Ambegaonkar JP, Caswell SV. Dance program administrators' perceptions of athletic training services. Athl Ther Today. 2009;14(3): 17-19.

163. Requa RK, Garrick JG. Do professional dancers have medical insurance? Company-provided medical insurance for professional dancers. J Dance Med Sci. 2005;9(3-4):81-83.

164. Wanke EM, Quarcoo D, Uibel S, Groneberg DA. Rehabilitation after occupational accidents in professional dancers: advice with due regard to dance specific aspects. Rehabilitation (Stuttg). 2012;51(4): 221-228. German.

165. Lai RY, Krasnow D, Thomas M. Communication between medical practitioners and dancers. J Dance Med Sci. 2008;12(2):47-53.

166. Leavesley RGE, Borthwick AM. Foot and lower-limb injury in ballet: dancers' perspectives. Br J Podiatry. 2003;6(3):73-79.

167. Russell JA, Wang TJ. Injury occurrence in university dancers and their access to healthcare. Proceedings of the International Association for Dance Medicine and Science Annual Meeting 2012; October 25-27; 2012; Singapore.

168. Chandler PA, Foster B. Health care services to performing artists: what do the artists think? Med Probl Perform Art. 1999;14:133-137.

169. Martinez SF, Murphy GA. Tibial stress fracture in a male ballet dancer: a case report. Am J Sports Med. 2005;33(1):124-130.
Open Access Journal of Sports Medicine

\section{Publish your work in this journal}

Open Access Journal of Sports Medicine is an international, peer-reviewed, open access journal publishing original research, reports, reviews and commentaries on all areas of sports medicine. The manuscript management system is completely online and includes a very quick and fair peer-review system.

\section{Dovepress}

Visit http://www.dovepress.com/testimonials.php to read real quotes from published authors. 